\title{
Challenges of Public Enterprises in Kosovo on Corporate Governance
}

\author{
Bahri Hyseni \\ PhD BahriHyseni, NH IbërLepenc,Sh.A., Republicof Kosovo \\ bahrihyseni@yahoo.com
}

\section{Doi:10.5901/ajis.2015.v4n1s2p57}

\begin{abstract}
Corporate governance has historically changed depending on the level of development of society, the economy and businesses. In terms of governance theoretical notion has undergone changes but today increasingly it is being understood as policies and monitoring implementation is done by the members of the governing body. In Kosovo with the entry into force of the Law on Companies No. 02 / L-123 in 2007 were established legal frameworks, for registration and operation of commercial companies in order to meet the practices and requirements of the European Union. Whereaswith the Law on Public Enterprises no. 03 / L-087it is set the legal framework for corporate governance of enterprises in accordance with internationally recognized principles of corporate governance of public enterprises. The problem of corporate governance in developed countries is widely researched but this problem in the case of public enterprise in Kosovo is less studied. Therefore, objective study includes the analysis of factors that affect the quality governance of public enterprises in Kosovo. The functioning of the board of directors as decision making factorin public enterprises is associated with various problems such as inexperience in policy making, political interference, and conflicts of interest. The paper aims to prove the hypothesis that corporate governance will improve the quality of governance. The paper is based on primary data published by the Policy and Monitoring Unit of Public Enterprises, and Public Enterprises. The paper also exposes some of the challenges that public enterprises face during the implementation of corporate governance. Thus, we will provide recommendations for improving corporate governance in public enterprises.
\end{abstract}

Keywords: public enterprises, corporate governance, services, challenges, board of directors

\section{Introduction}

The first international code of good corporate governance approved by governments was published in 1999 by the OECD-Principles of Corporate Governance. The main focuses of these Principles are publicly traded companies which are intended to assist governments in improving the legal, institutional and regulatory framework that supports corporate governance. This code provides practical guidance and suggestions for stock exchanges, corporations,investors and other parties that have relevant role in the process of developing corporate governance. Corporate governance institutions are different from on country to another, and experience with both developed and emerging economies has shown that there is no single framework which is appropriate for all markets. Thus, the Principles are not imperative, but instead they are in the form of recommendations where each country can respond to what it fits to its own traditions and market conditions. These principles have been widely adopted as a benchmark for good practice in corporate governance since 1999. Furthermore, these principles are used as one of 12 key standards by the Financial Stability Forum in order to ensure international financial stability and by the World Bank with the aim of improving corporate governance in emerging markets.

Since the Principles were published, a number of corporate scandals have undermined the confidence of investors in financial markets and company boards. Governments of the OECD in 2002, called for a review of the Principles in order to discuss these developments. On April 222004 a number of series and new recommendations were added to modify the principles which were approved by the OECD governments. The revised material is a result of a consultation process involving here OECD members and representatives from the OECD, non-OECD areas including professional and businesses bodies, trade unions, civil society organizations and international standard-setting bodies. The goal of these actors is to help policy makers in both developed and emerging markets to improve corporate governance in their jurisdictions, as a primary step in rebuilding public trust in companies and financial markets.

The reviewed Principles call for a more important role of shareholders in a number of important areas, including here executive remuneration and the appointment of board members. They invite enterprises to make sure that they have the necessary mechanisms to address possible conflicts of interest; there is a space forrecognizing and safeguard the 
rights of stakeholders, a framework where the internal complaints can be heard and adequate protection for individual whistleblowers. They point out the responsibilities of auditors to shareholders and the need for institutional investors acting in a fiduciary capacity such as pension funds and collective investment schemes to be transparent and open about how the ownership rights will be exercised. Thus, they invite enterprises boards to be truly accountable to shareholders and to take ultimate responsibility for their firmsin this way implementing high standard of corporate behavior and ethics.

Considering the recent development in the sector of cooperates and capital markets, the principles of cooperative governance actually are being applied continually in order to secure high quality services. From November 12, 2014 up to January 04,2015 , OECD has sent an invitation for the public commenting and the review of the draft text for the principles of cooperative governance. It is estimated that all the work related to the review will be completed by the end of 2015.

The process of the review of the principles of cooperative governance includes also the consultation with the business sector, professional groups in the international level, investors, economic chambers, non-governmental organizations, different shareholders and institutions responsible for the application of the international standards.

\section{Corporate Governance}

One of the goals of the principles of the cooperative governance is to help the Governments and regulators as instruments for the policy making in their efforts to evaluate and improve the legal framework, regulator and institutional cooperative governance. Thus, another goal of these principles is to contribute on the efficiency of the economic growth, sustainable growth, and financial sustainability.

\subsection{Models of the Cooperate Governance}

In difference countries there are applied difference models of corporate governance. Manly there are known two major models:

- Anglo-American model and

- German model

In OECD countries it is applied one of the models mentioned above.

Anglo-American model of the corporative governance or one level model is different from the German model because in its structure there is only one Board of Directors, as the main decision making body, which is also responsible to report to the shareholders. Management is responsible for the applicability of the policies and decisions of the Board of Directors.

Board of Directors has the competences for the selection of the management and other officials. In public enterprises in Kosovo it is applied Anglo-American model, the Board of Directors have the competences to select the Executive Director, Internal Auditor, Financial Officer, Treasury Officer, and Secretary of the enterprise. After the selection, the Executive Director based on the functions of the job position is also the member of the Board of Directors.

German Model has two levels of the corporative governance. Besides the Board of Directors it this model also has another board, the Supervisory Board. This board has the competences to revise the work and decision of the Board of Directors.

It is relevant to point out that these principles are aimed to be applied also in the countries which are not a member of the OECD with the purpose of increasing the level of corporative governance, accountability, and transparency for the public.

\subsection{Corporative governance and circumstances in Kosovo}

Even though it is argued that the models of corporative governance are have similarities there still differences between them. Countries might have differences on their history, culture, and legal framework. Thus, considering the time and circumstances when corporative governance began to be applied in Kosove, there have been significant differences to other countries. We will point out some of them as following:

- It didn't exist a legal framework for the implementation of the corporative governance unless the approval of the Law for the Trade Companies Nr.02/L-123 in 2007, and after that with the Law for Public Enterprises Nr. 03/L087 in 2008.

- The structure and the system of the organization of the enterprises before the process of transformation into 
public enterprises were in the form of social enterprises.

- From 1999 up to 2008 these enterprises have been administrated by the Kosovo Trust Agency, where the Supervisory Board appointed by the KTA was the main decision making body responsible for the management and policy making in these enterprises.

- Some of the enterprises have been the only operator on the certain sector (KEK-power supply, PTK-telecom) and they didn't have to face competition bringing them in the monopolistic situation.

* Lack of experience in the corporative governance including here the Board of Directors, and Auditing Comities.

\subsection{Challenges of implementation}

Up to the establishment of the public enterprises there was no opportunity for the applicability of the corporate governance. It isobvious that it waschallenging for all the participants involved in the process of the implementation of corporative governance.It is relevant to emphasize that domestic staff didn't have the necessary experience in cooperative governance, whereas the international staff was in the process of finishing their mission in Kosovo.

Even the process of establishment of Board of Directors, establishment and functionality of Unit for Policy and Monitoring of public enterprises, Ethics Code for cooperative governance, and applicability in practice of Law for public Enterprises was characterized with different difficulties.

These difficulties are present even after the implementation of the corporative governance. Thus, the goal of this research study is to improve the functionality and to improve the quality of the corporative governance.

\section{Challenges of Public Enterprises on Corporative Governance}

Some of the challenges that public enterprisers are facing which can increasing the level of corporative governance is to increase professional level of the Board of Directors, empowerment and increased level of monitoring of the Unit for the Policy and Monitoring, and transparency.

\subsection{Board of Directors}

From the selection of the members in the Board of Directs in 2008 up to now, the same persons are holding the positions they were named at the beginning. It is relevant to point out that only KEK and PTK in 2014 have changed the members of the Boards of Director. Also based on the decision of the Prime Minister of Kosovo after the expiration of the contract of all the members of Board of Director the contract was extended unless the next decision. There were two vacancy announcements for the member of Board of Directors in public enterprises but the vacancy was cancelled without explanation. The last vacancy posted during this year 2015, is the third for these position, which hopefully will end successfully.

Even though there are procedural problems in the selection process for the Board of Directors, it is more relevant the selection of the professionally qualified candidates as it is specified with the Law for Public Enterprises.Qualified candidates would give their relevant contribution in the process of the decision making in public enterprises. One of the mistakes which we wish will not be repeated will be the selection of the candidates that are hired in other institutions and are considered by Anti-corruption Agency as a conflict of interest. Conflict of the interest has been the main reason why enterprises such as "Ibër-Lepenci" and KRU "Prishtina", have had many resignations by the members in the Board of Directors. The work of the Board of Directors was very limited and didn't have positive trend due to this problems.

Another important problem which public enterprises in Kosovo are facing nowadays is the selection of the candidates based on the political preferences or the employment of the candidates which were involved in the activity of the political parties.

\subsection{Role of the Unit for Policy and Monitoring of Public Enterprises}

The Unit for the Policy and Monitoring of Public Enterprises operates in the level of the department in the Ministry of the Economic Development of the Government of the Republic of Kosovo. This unit works as special department which deals with the issues of the public enterprises and it supports the Ministry and Government in the process of supervising public enterprises.

This unit is also involved in the preparation and proposal of the procedures for the supervision of the public 
enterprises and monitoring the applicability of them in accordance with the Law for Public Enterprises. The active supervision of public enterprises requires high professional capacity and experience than the Unit really have. Up to now, the Unit didn't perform his function in the aspect of prevention but it has served more as corrective and consultative institution in regards to the applicable laws. Furthermore, the Unit couldn't offer a dynamic plan which would be implemented by the public enterprises and then to monitor the implementation process. We believe that an increased monitoring capacity and increased professional capacity would have direct effect in the process of facing the challenges in regards to the corporative governance.

\subsection{Reporting and Transparency level}

As we can observe from the review and approval of the reports from the Parliament of Kosovo it is shown that some reports are reviewed on delay (ex. Report of Performance of Public Enterprises during 2011 it was reviewed in Parliament of Kosovo on 29 March, whereas it was approved by the Parliament of Kosovo on April 04, 2013). This kind of delays have influenced the process of informing the Government even though they are the main shareholder in public enterprises, and every decision in is not in accordance with the actual situation in public enterprises. Decisions and transparency might not be as much effective as they should because of the changes in the situation. From what we have mentioned above, we can easily conclude that the reporting process from public enterprises to the Unit for Policy and Monitoring and Parliament should improve. This improvement can be achieved by applying laws that emphasize the deadline for the reporting period. It is important to stress out that there was confusion for the reporting period between the Code of Ethics, Corporative Governance for Public Enterprises and Law for Public Enterprises. This Code has been republished in July again and we hope that the misunderstandings from the previous publication have been eliminated.

\section{Conclusion}

We can conclude that Corporative Governance in Public Enterprises have improved a lot since the establishment in public enterprises in Kosovo. Continually there were improvements in the functionality of Corporate Governance in Public Enterprises. However, there are still challenges in the process of implementation. We believe that successful overcoming of these challenges would bring success in the process of decision making in public enterprises but also it will increase the quality of public services.

Some of the recommendations that would help on the improvement of the corporative governance include: selection of the members of the Board of Directors based on the deadline, setting out the mandates for the member of the Boards of Directors, the process of Member selection should be based on the academic and processional achievements but also experience, and empowerment of the Unit for the Policy and Monitoring of Public Enterprises.

\section{References}

Bank, T. W. (Janary 2013). Kosovo Country Environmental Analysis. The World Bank.

Bouchez, L. (n.d.). Principles of corporate governance: The OECD perspective.

Ekonomik, R. e. (2011). Raporti i Performancës së Ndërmarrjeve Publike 2010. Prishtine: Ministria e Zhvillimit Ekonomik.

Instituti Kosovar për Kërkime dhe Zhvillim të Politikave. (2011). Menaxhimi publik: Analizë e bordeve të ndërmarrjeve publike dhe agjencive të pavarura. Prishtine: KIPRED.

KOSOVËS, K. E. (Janar 2012). Raporti per Performancen per Vitin 2011. Prishtine: KORPORATA ENERGJETIKE E KOSOVËS .

KOSOVO, S. A. (2011). Series 3: Economic Statistics - Statistical Repertoire of Enterprises. Prishtine: STATISTICAL AGENCY OF KOSOVO.

OECD principles of corporate governance. (1999). Paris: OECD.

OECD principles of corporate governance. (2004). Paris: OECD.

Prishtina sh.a, K. e. (March 2013). Raporti Vjetor KRU Prishtina 2012. Prishtine: Kompania e Ujesjellesit Regjional "Prishtina"sh.a.

Republic of Kosovo- Assembly . (n.d.). Law No. 03/L-087 ON PUBLICLY OWNED ENTERPRISES. Retrieved March 29, 2011, from http://www.assembly-kosova.org: http://www.assembly-kosova.org/common/docs/ligjet/2008_03-L087_en.pdf

Thornton, G. (2011, December 31). http://www.kek-energy.com/rapFinanca.asp. Retrieved August 20,12fromhttp://www.kekenergy. com/doc/publikime/KEK\%20Pasqyrat\%20Financiare\%202011\%20ALB.PDF 